\title{
ALUMINUM MATRIX COMPOSITES REINFORCED WITH NANO TiC PARTICLES: MICROSTRUCTURE AND WEAR BEHAVIOR
}

\author{
KOMPOZITI NA OSNOVI ALUMINIJA, OJAČANI Z NANO TiC \\ DELCI: MIKROSTRUKTURA IN ODPORNOST PROTI OBRABI
}

\author{
Yalin $\mathrm{Lu}^{1}$, Dongshuai Zhou ${ }^{1}$, Xingcheng $\mathrm{Li}^{1}$, Jian Wang ${ }^{2}$, Wen $\mathrm{Li}^{2}$, Zhihao Bai ${ }^{2}$ \\ ${ }^{1}$ Key Laboratory of Advanced Materials Design and Additive Manufacturing of Jiangsu Province, no. 1801 Zhongwu Road, \\ Changzhou, Jiangsu, 213001 China \\ 2Jiangsu University of Technology, School of Materials Engineering, no. 1801 Zhongwu Road, Changzhou, Jiangsu, 213001 China \\ luyalin@163.com \\ Prejem rokopisa - received: 2018-01-02; sprejem za objavo - accepted for publication: 2018-05-31
}

doi:10.17222/mit.2018.001

TiC/7085 aluminum matrix composites (AMCs) were prepared by the in-situ reaction casting technique. The effects of the nano TiC particles on the microstructure were investigated by light microscopy, X-ray diffractometer, SEM and TEM. The in-situ nano TiC particles showed an obvious effect on the grain refinement of the as-cast microstructure of 7085 aluminum alloy matrix, leading to a microstructural transformation from the coarse dendritic grains to the fine equiaxed grains. The wear resistance of the AMC was further characterized using a NANOVEA micro tribometer. It was found that the wear rate of the AMC decreased and the wear resistance was enhanced due to the additions of the nano TiC particles. The wear mechanism of the TiC/7085 composites was mainly composed of abrasive and adhesive wear.

Keywords: in-situ TiC particle; 7085 aluminum alloy; microstructure; wear behavior

Avtorji prispevka so kompozite s kovinsko osnovo na osnovi Al zlitine (AMCs; angl.: Aluminum Matrix Composites) vrste 7085 in ojačane $\mathrm{z}$ nano TiC delci (TiC/7085) pripravili z insitu reakcijsko livarsko tehniko. Vpliv nano TiC delcev na mikrostrukturo so preiskovali z optično (LM), vrstično (SEM) in presevno (TEM) elektronsko mikroskopijo ter rentgensko difrakcijo (XRD). Insitu nastali nano TiC delci očitno vplivajo na udrobljenje (zmanjšanje velikosti kristalnih zrn) v liti strukturi kovinske osnove (matrice); to je Al zlitine 7085, kar vodi k pretvorbi njene mirostrukture iz grobih dendritnih kristalnih zrn $v$ fina enakoosna kristalna zrna. Odpornost AMC kompozita proti obrabi so določili z NANOVEA mikro tribometrom. Ugotovili so, da se obraba kompozita zmanjšuje in odpornost proti obrabi izboljšuje z dodatkom nano TiC delcev. Mehanizem obrabe $\mathrm{TiC} / 7085$ kompozitov je $\mathrm{v}$ glavnem sestavljen iz abrazivne in adhezivne obrabe.

Ključne besede: in-situ sinteza TiC delcev; aluminijeva zlitina tipa 7085; mikrostruktura; odpornost proti obrabi

\section{INTRODUCTION}

Particle-reinforced, metal-matrix composites with excellent high-temperature mechanical properties and wear resistance have been widely used in the aerospace, automotive, chemical, and transportation industries. ${ }^{1-5}$ The particles generally used include boride $\left(\mathrm{ZrB}_{2}, \mathrm{TiB}_{2}\right)$, carbide $(\mathrm{SiC}, \mathrm{TiC})$, nitride $\left(\mathrm{AlN}, \mathrm{Si}_{3} \mathrm{~N}_{4}\right)$, and oxide $\left(\mathrm{Al}_{2} \mathrm{O}_{3}, \mathrm{SiO}_{2}\right){ }^{6-8}$ The reinforced ceramic particles embedded in the matrices of hybrid composite materials have been shown to improve the wear-resistance properties compared to the base alloys. For example, Gopalakrishnan Elango and co-workers studied the wear-resistance properties of $\mathrm{SiC}$ and $\mathrm{TiO}_{2}$-particlesreinforced LM25 Al matrix composites. The results showed that the reinforcement of the metal matrix with $\mathrm{SiC}$ and $\mathrm{TiO}_{2}$ reduced the wear rate at room temperature. ${ }^{9}$ Jayasheel Harti and co-workers investigated the dry-sliding wear behavior of TiC-2219 Al matrix composites. ${ }^{10}$ The results showed that the wear resistance of the composites was better than the unreinforced alloy. On the other hand, the researchers showed that the composites reinforced by nano-sized particles have better properties than those reinforced by micro-sized particles. ${ }^{11}$ Recently, the high-temperature mechanical properties and wear resistance of the $7 \mathrm{xxx}$ aluminum alloy have been improved by adding nano TiC particles in-situ. For example, Xu et al. ${ }^{13}$ investigated the effects of in-situ nano TiC particles on the microstructure and tribological properties of a 7075 aluminum alloy. ${ }^{12}$ Azimi et al. ${ }^{13}$ studied the effect of the hot-pressing temperature and the grinding time of nano TiC particles on the strength of the nano composites. Ning et al. ${ }^{14}$ studied the effects of Al-5Ti-0.2C refiner on the nucleation and undercooling behavior of 7085 aluminum alloys by changing the mass fraction of Al-Ti-C refiners added to 7085 aluminum alloy during solidification.

As a typical representative of the 7xxx super-highstrength aluminum alloy, 7085 aluminum exhibits many advantages, such as high strength, low density and high modulus for various industrial applications. Many investigations on the in-situ synthesis and performance of nanoparticles reinforced 7075 aluminum matrix composites were reported, but the study on the performance of 7085 aluminum matrix composites reinforced using the in-situ TiC particles is very limited. ${ }^{15-18}$ 
In the present work, the $1 \%$ nano TiC particle reinforced 7085 matrix composite was produced by in-situ reaction casting. The effects of the in-situ TiC particles on the microstructure and wear resistance were investigated using SEM, EDS, TEM and XRD. The aim of this study was to establish a relationship between the microstructure and the wear properties of the nano $\mathrm{TiC} / 7085$ composite. Our results will provide a practical approach to preparing Al matrix composites with a high wear resistance.

\section{EXPERIMENTAL PART}

\subsection{Preparation of the composites}

The powders of $\mathrm{Al}, \mathrm{Ti}$, and carbon nanotubes (CNTs) were proportionally mixed by ball milling for $48 \mathrm{~h}$ at the speed of $60 \mathrm{~min}^{-1}$. Then, the mixed powder was pressed into cylindrical green compacts with a diameter of 60 $\mathrm{mm}$ and a height of $25 \mathrm{~mm}$, and the theoretical density of the green compact was about $65 \%$. The in-situ reaction of the green compact was conducted in a vacuum at 950 ${ }^{\circ} \mathrm{C}$ for $10 \mathrm{~min}$ to form the nano TiC-Al master alloy. The 7085 aluminum alloy was melted at a temperature of $900{ }^{\circ} \mathrm{C}$. The nano TiC-Al master alloy was placed in an electrical resistance furnace at a temperature of $500{ }^{\circ} \mathrm{C}$ for $2 \mathrm{~h}$, and then put into 7085 aluminum alloy melts quickly for $15 \mathrm{~m}$ after mechanical stirring. After degassing refining, the 7085 aluminum alloy melts were poured into a mold (preheated at a temperature of $\left.250{ }^{\circ} \mathrm{C}\right)$.

\subsection{Microstructural observations}

The main chemical composition for the 7085 aluminum alloy in the present work was Al-7.5\% Zn-1.6\% $\mathrm{Mg}-1.5 \% \mathrm{Cu}-0.11 \% \mathrm{Zr}$. The square samples with $65 \mathrm{~mm}$ in length, $40 \mathrm{~mm}$ in width, and $20 \mathrm{~mm}$ in height were machined using wire electrical discharge machining (WEDM), and then were homogenized at $465{ }^{\circ} \mathrm{C}$ for $24 \mathrm{~h}$ in a box. Rolling processing was performed at a temperature of $430{ }^{\circ} \mathrm{C}$ for $1 \mathrm{~h}$ with a total rolling deformation of $80 \%$. Two kinds of samples were solution treated at $480{ }^{\circ} \mathrm{C}$ for $3 \mathrm{~h}$ and aging treated at $120{ }^{\circ} \mathrm{C}$ for $24 \mathrm{~h}$, respectively.

The microstructures of samples were characterized using a light microscope (LM), a scanning electron microscope (SEM) and an energy-dispersive spectrometer (EDS). Samples for LM observation were chemically etched in Gaff's reagent and Keller reagent. The phases were analyzed by a D8 ADVANCE type X-ray diffractometer (XRD) operated at $35 \mathrm{KV}$ and $30 \mathrm{~mA}$ with $\mathrm{Cu}-K_{\alpha}$ radiation $(k=0.15406 \mathrm{~nm})$, and the XRD patterns were collected over the $2 \theta$ range $10-90^{\circ}$ with a scanning speed of $4 \% \mathrm{~min}$. For the TEM observations, the samples were mechanically thinned to a thicknesses of about 80 $\mu \mathrm{m}$, punched into foils of $3 \mathrm{~mm}$ in diameter, and electropolished in $30 \% \mathrm{HNO}_{3}$ and $70 \% \mathrm{CH}_{3} \mathrm{OH}$ solution below $-30{ }^{\circ} \mathrm{C}$. The analysis was performed with a JEOL-2100F transmission electron microscope (TEM) that was operated at $200 \mathrm{kV}$.

\subsection{Wear tests}

The wear tests were carried out on a micro NANOVEA machine in the form of dry friction. T8 steel was used as the grinding materials, and its outer shape was spherical. The wear loss was measured using a SP2001 electronic analytical balance. The load pressure of the wear test was $5 \mathrm{~N}$. The samples were cleaned in the ultrasonic cleaning instrument before and after the dry wear tests. The speed was $200 \mathrm{~min}^{-1}$, and the friction time was $10 \mathrm{~min}$. The wear resistance was analyzed by the volume wear rate, and the calculation formula of the volume wear rate was as follows: ${ }^{6}$

$$
W_{\mathrm{s}}=\frac{V_{\mathrm{L}}}{L}=\frac{\Delta m}{\rho_{x} \times v \times t}
$$

Note: $V_{\mathrm{L}}$ - wear volume $\left(\mathrm{m}^{3}\right), L-$ wear distance $(\mathrm{m})$, $\Delta m$ - the loss weight $(\mathrm{kg}), \rho_{x}-$ alloy density, $v-$ sliding velocity of sample, and $t-$ wear time ( $\mathrm{min})$.

\section{RESULTS AND DISCUSSION}

\subsection{Microstructure characterizations}

Figure 1 shows the $\mathrm{TiC}$ particles in the $\mathrm{TiC}-\mathrm{Al}$ master alloy. It can be seen that the formed $\mathrm{TiC}$ particles are with sizes in the range 50-200 $\mathrm{nm}$ and irregular shapes.

Figure 2 shows the as-cast microstructure of $7085 \mathrm{Al}$ matrix and $1 \% \mathrm{TiC} / 7085$ composites. The coarse grains, dendrite microstructure and needle-shape precipitated $\eta$ phases can be seen in the as-cast microstructure of 7085 aluminum alloy matrix. The grain size decreased obviously, and the shape was equiaxed in $1 \% \mathrm{TiC} / 7085$ composites. This happened because the lattice constants of the TiC particles were similar to those of aluminum, which satisfies the lattice-matching principle. ${ }^{15}$ This also

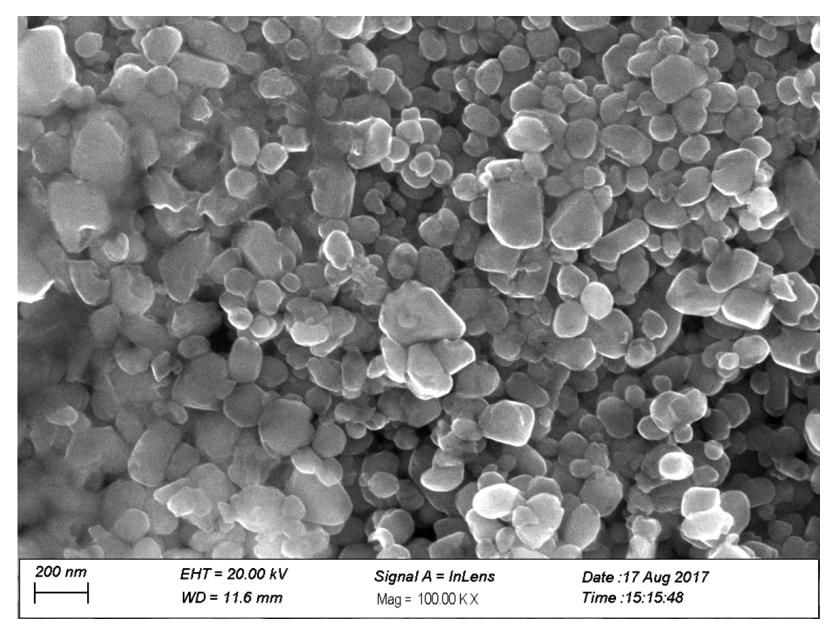

Figure 1: Morphology of the $\mathrm{TiC}$ particles in the $\mathrm{TiC}-\mathrm{Al}$ master alloy 

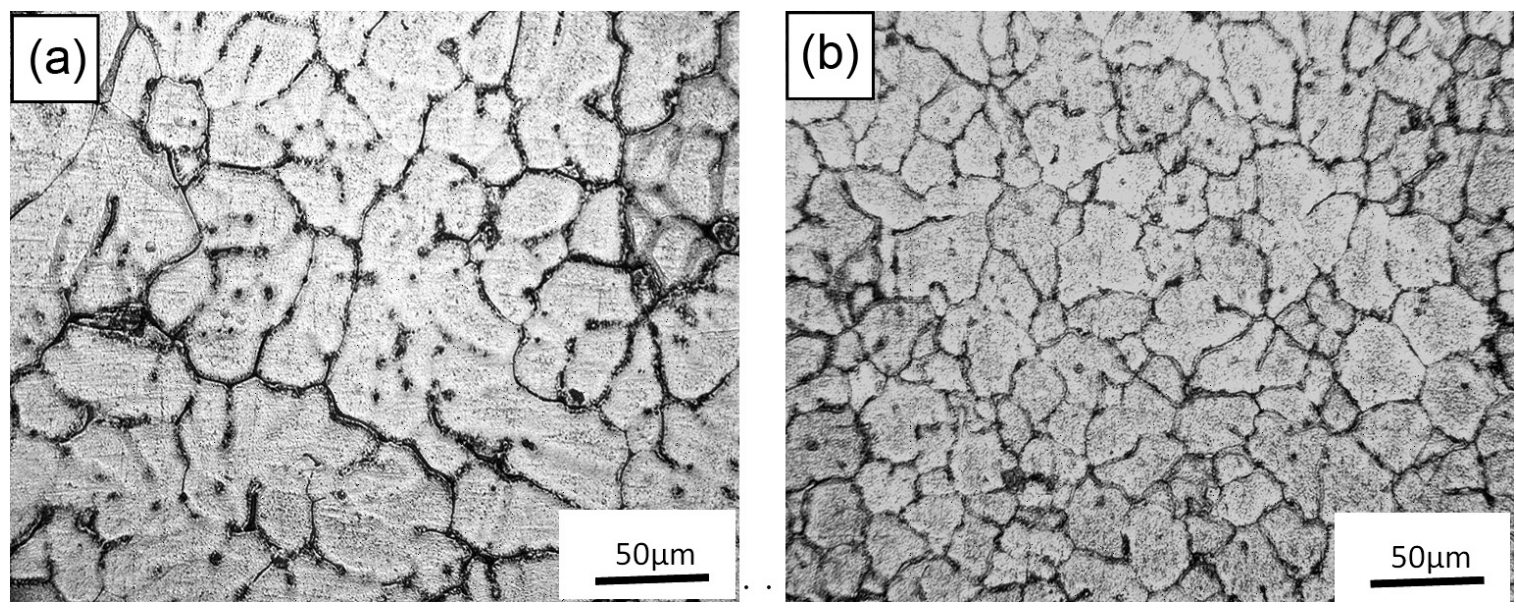

Figure 2: As-cast microstructure of the $\mathrm{Al}$ alloys with: a) $7085 \mathrm{Al}$ matrix, b) $1 \% \mathrm{TiC} / 7085 \mathrm{Al}$ composite

indicates that the in-situ TiC particles could act as new nucleation sites in aluminum melts to reduce the wetting angle and nucleation energy. At the same time, because these particles could also reduce the undercooling degree for the nucleation, the total nucleation number in the alloy melts could be saturated. As a result, the growth of aluminum grains can be hindered, and the in-situ TiC particles can significantly refine the grains of the composites.

Figure 3 shows the EBSD images of the 7085 aluminum alloy matrix and $1 \%$ TiC/7085 aluminum alloy composite after the hot rolling and the $\{110\}$ pole figures. The grain orientations show that the 7085 aluminum alloy matrix was fully recrystallized, the average
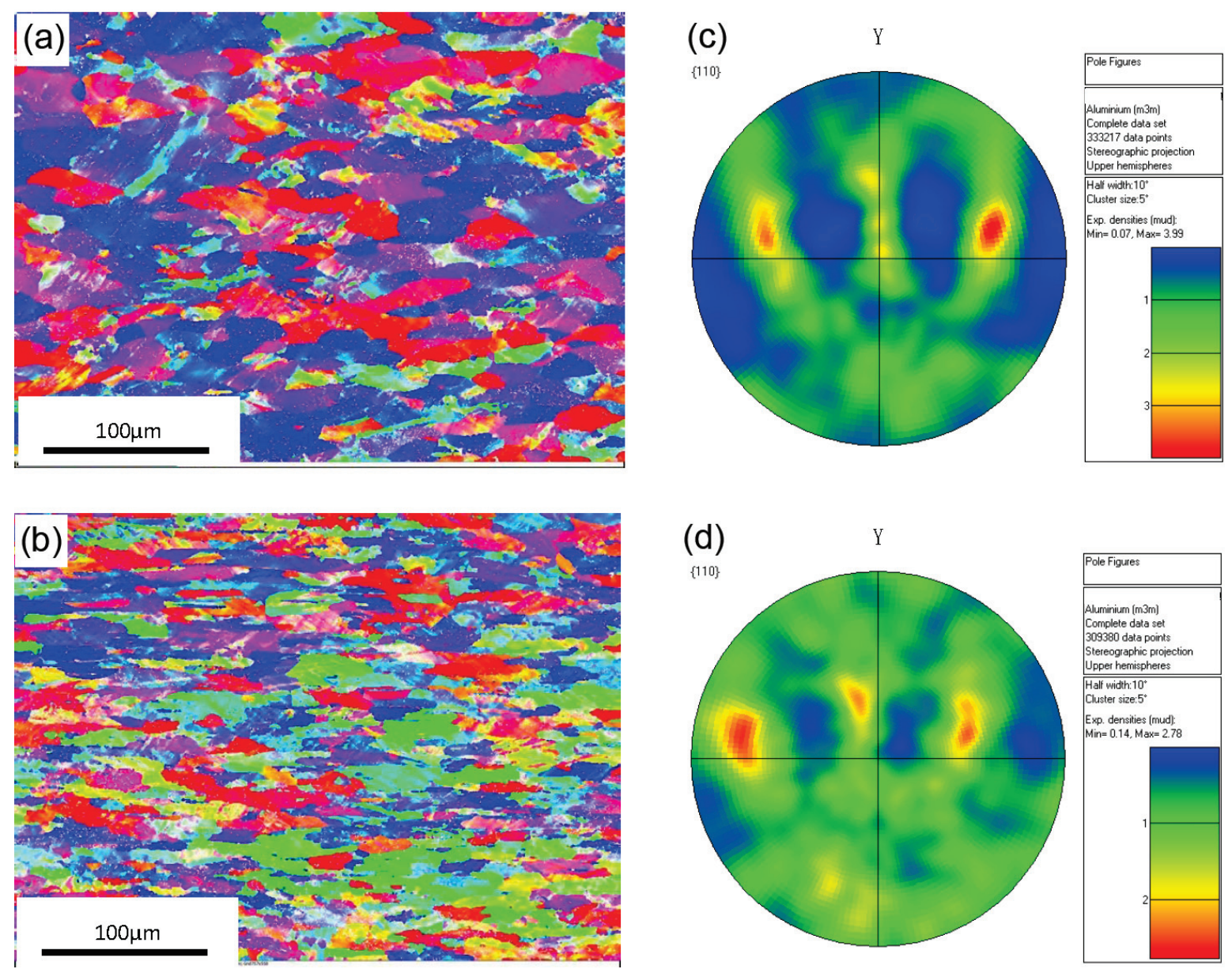

Figure 3: a) EBSD images of 7085 aluminum alloy matrix and b) $1 \%$ TiC/7085 aluminum alloy composite after hot rolling and c) $\{110\}$ pole figures of 7085 aluminum alloy matrix and d) $1 \% \mathrm{TiC} / 7085$ aluminum alloy composite 


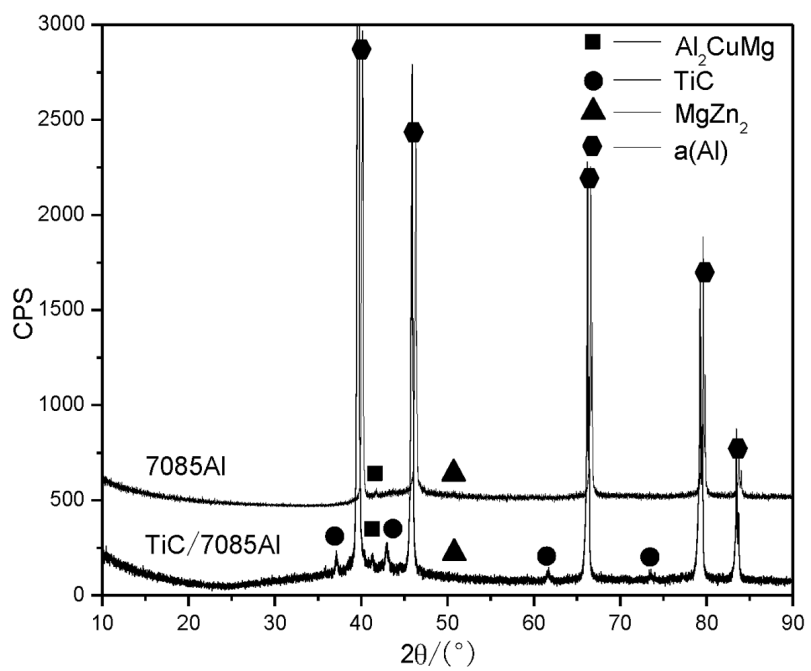

Figure 4: XRD spectrum of $\mathrm{TiC} / 7085$ composites and 7085Al matrix

grain size was $11 \mu \mathrm{m}\left(\geq 1^{\circ}\right)$. However, the microstructure of the $1 \% \mathrm{TiC} / 7085$ composite has a fibrous tissue, and the average grain size was $6.95 \mu \mathrm{m}\left(\geq 1^{\circ}\right)$. At the same time, the texture strength of the $1 \% \mathrm{TiC} / 7085$ aluminum alloy composites was smaller than that of the 7085 aluminum alloy matrix. These results indicate that the addition of in-situ TiC nanoparticles can inhibit the recrystallizations during the hot deformation, leading to the weakening of the texture strength. Figure 4 shows

the XRD analysis of the TiC/7085 composites. Compared with the PDF card, the main X-ray diffraction characteristic peaks were two phases of $\mathrm{Al}$ and $\mathrm{TiC}$.

Figure 5 shows the distribution and morphology of the in-situ TiC particles observed by SEM and TEM. It is clear that the in-situ TiC particle with a spherical shape was bright, and its diameter was smaller than $1 \mu \mathrm{m}$. We can also see that the agglomeration phenomenon of the in-situ nano $\mathrm{TiC}$ particles at the grain boundaries occurred. During the process of high temperature preparations, the products produced by the thermal explosion reaction diffused into the aluminum melts to make the in-situ particles dispersed in the matrix uniformly. Moreover, the uniform equiaxed grains indicate that the in-situ TiC particles with refinement of microstructure were uniformly distributed. In addition, because the interaction of the nano TiC particles could inhibit the movement of dislocations and hence cause the dislocations stacked at the grain boundaries, the recrystallization degree was decreased in the deformation process.

\subsection{Hardness and wear resistance}

Figure 6 shows the mechanical properties for the T6 aging of 7085 aluminum alloy matrix and TiC/7085Al composites. As seen, the mechanical properties of the
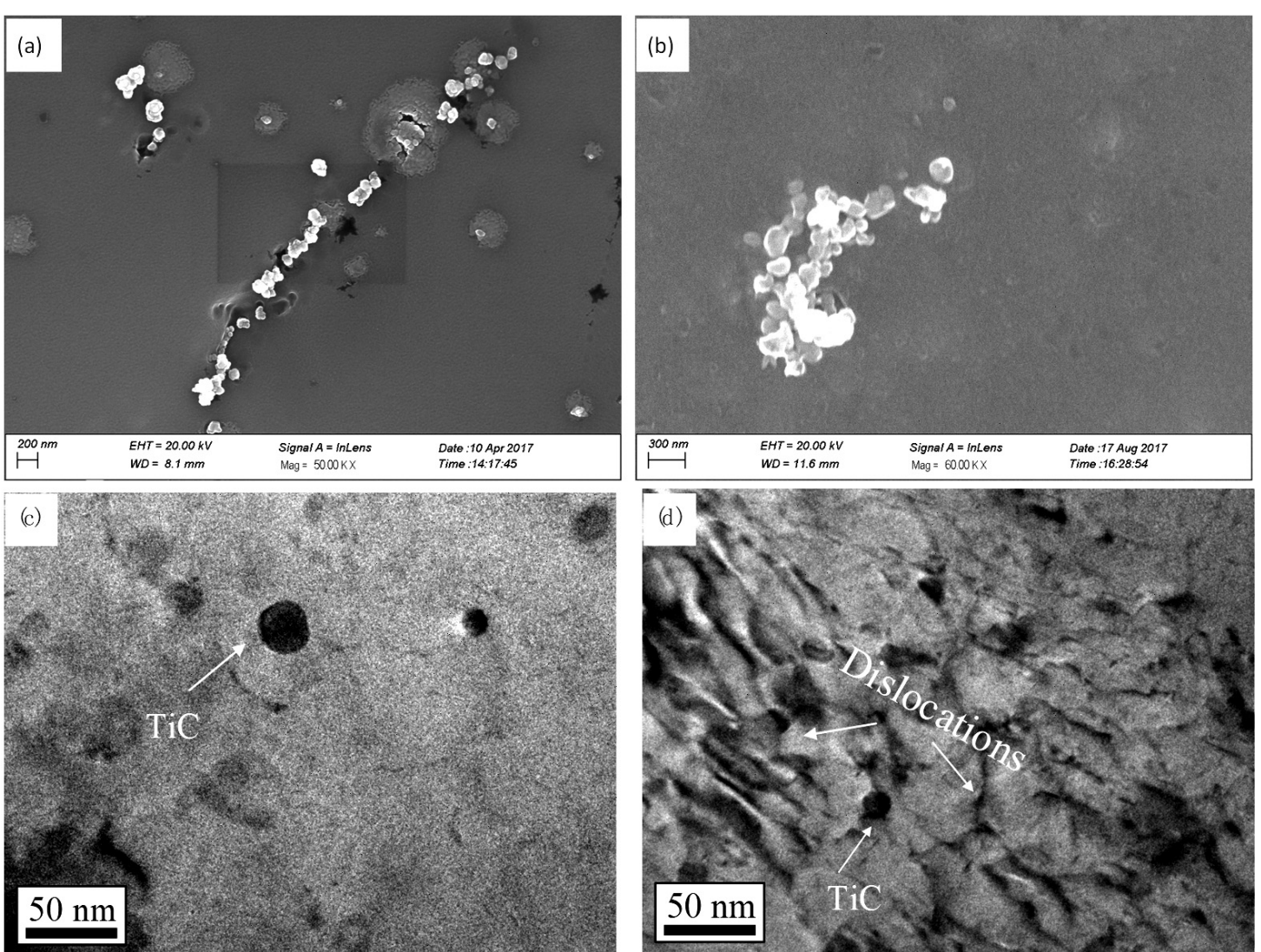

Figure 5: Distribution and morphology of the in-situ TiC particles observed under SEM and TEM: a) grain boundaries, b) intragranular, c) TEM morphologies of $\mathrm{TiC}$ particles, d) dislocations near TiC particles 


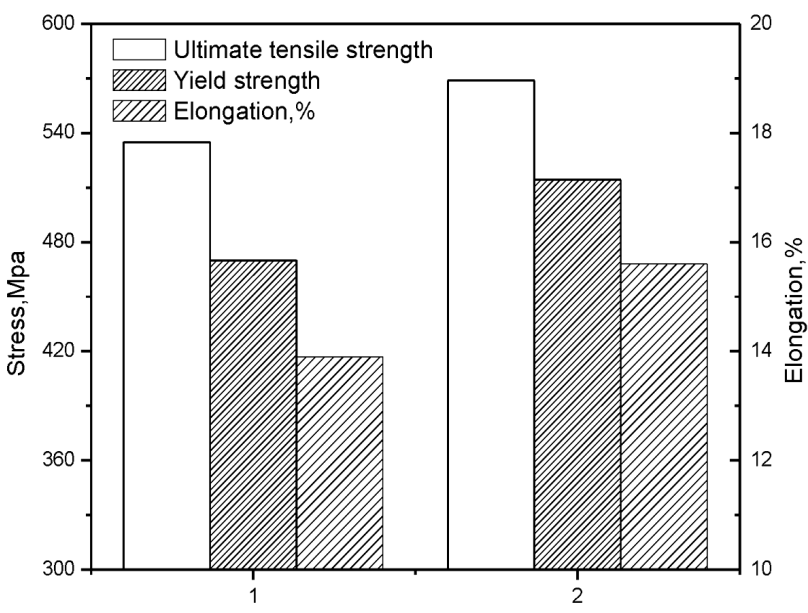

Figure 6: Comparison of the mechanical properties for the 7085 aluminum alloy matrix (1) and the TiC/7085Al composite (2) after T6 treatments

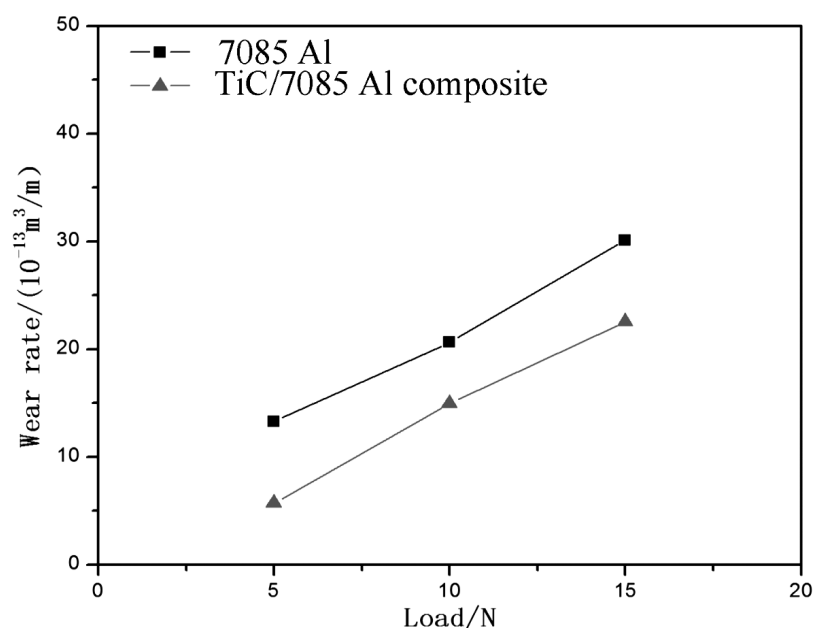

Figure 7: Wear rate of $7085 \mathrm{Al}$ matrix and $\mathrm{TiC} / 7085 \mathrm{Al}$ composites under different loads

composites were larger than those of the matrix materials. Figure 7 shows the changing curve of the wear rate of the matrix and the composites under different loads. As seen, with the increase of the load, the wear rates of both the matrix and composites increased, indicating excellent tribological properties, but the wear mass loss of the composites was significantly lower than that of the matrix. This indicates that the addition of $\mathrm{TiC}$ particles can greatly improve the wear resistance of 7085 aluminum alloys.

\subsection{Observation of worn-surface morphology}

Figure 8 shows the surface wear morphology of the samples of the two materials. Compared with the TiC/7085 composites, the wear surface of the 7085 aluminum alloys showed deep furrow stripes, and various tear marks were perpendicular to the wear direction. In order to make a further analysis on the wear mechanism, the worn surface morphology was observed. The SEM
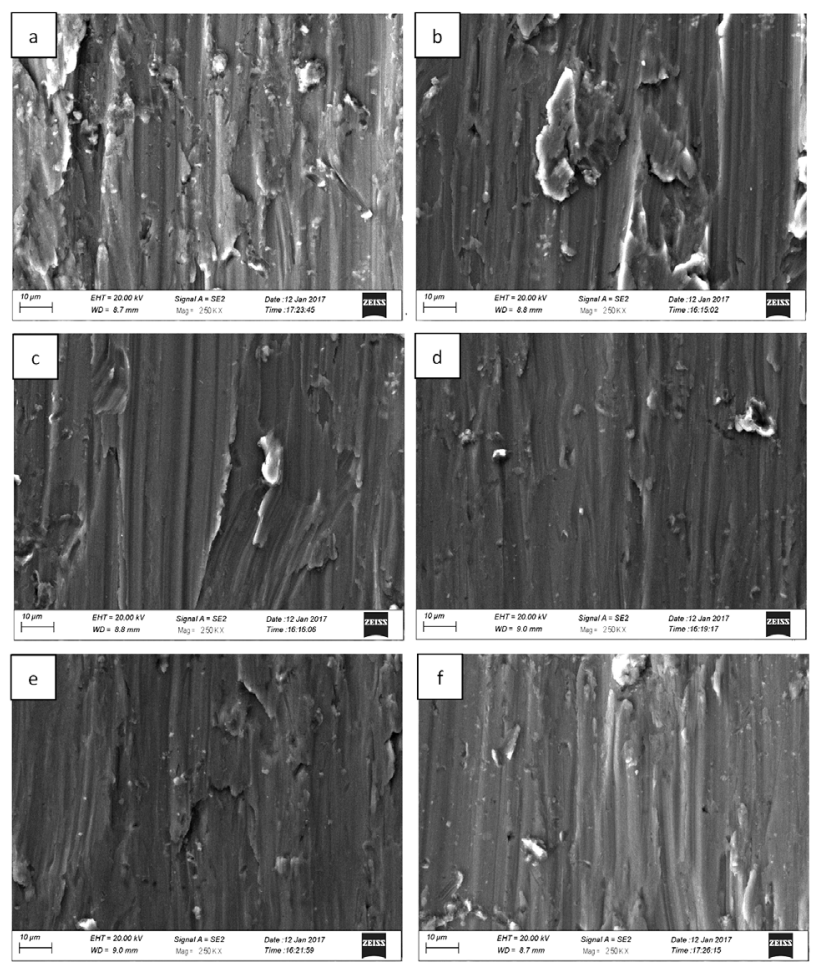

Figure 8: Worn surface morphology of 7085 alloy (SEM) with the load: a) $5 \mathrm{~N}$, b) $10 \mathrm{~N}$, c) $15 \mathrm{~N}$ and the load on the TiC/7085 $\mathrm{Al}$ composite with d) $5 \mathrm{~N}$, e) $10 \mathrm{~N}, \mathrm{f}) 15 \mathrm{~N}$

morphology of the 7085 aluminum alloy matrix under the different loading conditions shows that the wear surface was rough with deep plough traces and plastic adhesion caused by the abrasive wear. The SEM morphology of the TiC/7085 composite under the different loads indicates that the surface was still smooth in spite of some obvious furrows and wear scars with the addition of TiC particles. Compared with the base materials, the composite surface was smooth, and the furrows were shallow and narrow, because of the TiC particles. Furthermore, based on the morphological observations, it is understandable that the wear resistance of the $\mathrm{TiC} / 7085$ composites was better than that of the 7085 aluminum alloy matrix because the cemented TiC particles in the composites played an important role in bearing properties under the conditions of low loads. In other words, if the soft substrate was worn out under the external force, the in-situ TiC particles played a buffer role in the friction between the opposite gridding ball and the soft substrate, and hence reduced the wear degree. ${ }^{19,20}$

\section{CONCLUSIONS}

(1) The in-situ nano TiC particles had an obvious effect on the grain refinement of the as-cast microstructure of the 7085 aluminum alloy matrix, leading to a microstructural transformation from the coarse dendritic grains to the fine equiaxed grains. 


\section{Y. LU et al.: ALUMINUM MATRIX COMPOSITES REINFORCED WITH NANO TIC PARTICLES ...}

(2) Compared with the 7085 aluminum alloy matrix, the adding of in-situ nano TiC particles improved the wear resistance for the same wear speed and time. The wear mechanism of the TiC/7085 composites was mainly composed of abrasive and adhesive wear.

\section{Acknowledgements}

This research is supported by the National Science Foundation of China (no. 51601079 and no. 51801084), the Integration of Industry, Education and Research of Jiangsu Province (no. BY2016030-17) and the Major Project of Education Department, Jiangsu Province (no. 17KJA43005 and no. 18KJA43007).

\section{REFERENCES}

${ }^{1}$ S. C. Tjong, M. D. Ma, Microstructural and mechanical characteristics of in situmetal matrix composites, Mater. Sci. Eng. R, 29 (2000), 49-113, doi:10.1016/S0927-796X(00)00024-3

${ }^{2}$ A. Lekatou, A. E. Karantzalis, Aluminium reinforced by WC and TiC nanoparticles (ex-situ) and aluminide particles (in-situ): Microstructure, wear and corrosion behavior, Mater. Des., 65 (2015), 1121-1135, doi:10.1016/j.matdes.2014.08.040

${ }^{3}$ Y. D. He, K. X. M. Zhang, J. H. You, Effect of minor Sc and Zr on microstructure and mechanical properties of $\mathrm{Al}-\mathrm{Zn}-\mathrm{Mg}-\mathrm{Cu}$ alloy, Trans. Nonfer. Metal Soc. China, 16 (2006) 5, 1228-1235, doi:10.1016/S1003-6326(06)60406-8

${ }^{4}$ N. Nemati, R. Khosroshahi, M. Emamy, A. Zolriasatein, Investigation of microstructure, hardness and wear properties of Al-4.5 w/\% $\mathrm{Cu}-\mathrm{TiC}$ nanocomposites produced by mechanical milling, Mater. and Des., 7 (2011), 3718-3729, doi:10.1016/j.matdes.2011.03.056

${ }^{5} \mathrm{~S}$. Baskaran, V. Anandakrishnan, Investigations on dry sliding wear behavior of in situ casted AA7075-TiC metal matrix composites by using taguchi technique, Mater. and Des., 60 (2014), 184-192, doi:10.1016/j.matdes.2014.03.074

${ }^{6}$ L. R. Deaquino, E. Gutiérrez-Castaneda, G. I. Estrada, R. G. Hinojosa, Structural characterization of aluminum alloy 7075-graphite composites fabricated by mechanical alloying and hot extrusion, Mater. and Des., 53 (2014), 1104-1111, doi:10.1016/j.matdes. 2013.08.005

${ }^{7}$ D. G. Zhao, X. F. Liu, Y. X. Liu, In-situ preparation of Al matrix composite reinforced by $\mathrm{TiB}_{2}$ articles and sub-micron $\mathrm{ZrB}_{2}$, J. Mater. Sci. L., 40 (2005), 4365-4358, doi:10.1007/s10853-005-0796-3

${ }^{8}$ L. Lu, M. O. Lai, J. L.Yeo, In situ synthesis of TiC composite for structure application, Compos. Struct., 14 (1999), 613-618, doi:10.1016/S0263-8223(00)00032-5
${ }^{9}$ G. Elango, B. Raghunath, K. Palanikukmar, Experimental analysis of the wear behavior of hybrid metal-matrix composites of LM25Al with equal volumes of $\mathrm{SiC}+\mathrm{TiO}_{2}$, MATEC9, 48 (2014), 803-810, doi:669.715:620.178.16:539.92

${ }^{10}$ I. Jayasheel, T. B. Harti, N. Madeva, J. Pankaj, V. Auradi. Microstructure and dry sliding wear behaviour of Al2219-TiC composites, Mater. Today: Proc., 4 (2017), 11004-11009, doi:10.1016/j.matpr. 2017.08.058

${ }^{11}$ N. Selvakumar, M. Sivaraj, S. Muthuraman. Microstructure characterization and thermal properties of Al-TiC sintered nano composites, Appl. Ther. Eng., 107 (2016), 625-632, doi:10.1016/ j.applthermaleng.2016.07.005

${ }^{12}$ P. Xu, Y. Q. Wang, Z. D. Song, H. M. Liu, Effect of in-situ TiC particles on microstructure and wear properties of 7075 aluminum alloy, Lig. Alloy Fabric. Technol., 2 (2011), 55-59, doi:10.1016/j.matchar. 2005.01.011

${ }^{13}$ A. Azimi, A. Shokuhfar, A. Zolriasatein, Nanostructured Al-Zn$\mathrm{Mg}-\mathrm{Cu}-\mathrm{Zr}$ alloy prepared by mechanical alloying followed by hot pressing, Mater. Sci. Eng. A, 595 (2014), 124-130, doi:10.1016/ j.msea.2013.11.094

${ }^{14}$ J. J. Ning, X. Q. Li, R. P. Jiang, M. Z. Huang, Effect of Al-5Ti-0.2C refiner on nucleation and undercooling degree of 7085 aluminum alloy, Sci. Technol., 8 (2015), 2837-2842, doi:10.13140/RG.2.1.2049. 2884

${ }^{15}$ H. M. Liu, B. Hao, Refinement mechanism of in-situ TiC particles on the microstructure of spray formed $7075 \mathrm{Al}$ alloys, J. University Sci Technol. Beijing, 4 (2006), 369-372, doi:10.13374/j.issn1001 053x.2006.04.014

${ }^{16}$ H. M. Liu, Z. D. Song, P. Xu, J. Zhang, Experimental study of the wear resistance of TiC/7075 Al matrix composite, J. Mater. Eng., 7 (2011), 66-70, doi:10.3969/j.issn.1001-4381.2013.06.001

${ }^{17}$ N. Yazdian, F. Karimzadeh, M. Tavoosi, Microstructural evolution of nanostructure 7075 aluminum alloy during isothermal annealing, J. Alloy Compd., 493 (2010), 137-141, doi:10.1016/j.jallcom.2009. 12.144

${ }^{18}$ D. S. Zhou, J. Tang, F. Qiu, J. G. Wang, Q. C.Jiang, Effects of nanoTiCp on the microstructures and tensile properties of $\mathrm{TiCp} / \mathrm{Al}-\mathrm{Cu}$ composites, Mater. Charact., 94 (2014), 80-85, doi:10.1016/ j.matchar.2014.05.012

${ }^{19}$ R. L. Jang, Y. T. Zhao, Q. X. Dai, Dry sliding wear characteristics and mechanism of in-situ composites synthesized by $\mathrm{A} 359-\mathrm{Zr}\left(\mathrm{CO}_{3}\right)_{2}$ reaction system, Chin. J. Nonfer. Metals, 9 (2004), 1621-1626, doi:10.19476/j.ysxb .1004.0609.2004.09.032

${ }^{20}$ D. S. Zhou, F. Qiu, Q. C. Jiang, The nano-sized TiC particle reinforced $\mathrm{Al}-\mathrm{Cu}$ composite with superior tensile ductility, Mater. Sci. Eng. A, 622 (2015), 189-193, doi:10.1016/j.msea.2014.11.006 